\title{
EVALUASI PENGGUNAAN ANTIBIOTIKA BERDASARKAN KONTRAINDIKASI, EFEKSAMPING, DAN INTERAKSI OBAT PADA PASIEN RAWAT INAP DENGAN INFEKSI SALURAN PERNAPASAN BAWAH DI RUMAH SAKIT PANTI RAPIH YOGYAKARTA PERIODE JANUARI-JUNI 2005
}

\author{
Fajar Prasetya \\ Kelompok Bidang Ilmu Farmasi Klinik, Fakultas Farmasi, Universitas Mulawarman \\ e-mail: fajarprasetya@farmasi.unmul.ac.id
}

\begin{abstract}
The non-TBC lower respiratory infection is a kind of infection that can attack bronchus, bronchioles and lung, the clinical manifestation can chronicle and severe. Generally the caused in children is virus and bacteria while in adult is bacteria, which is using antibiotics in medical attention. The purpose of research is to find out the infection pattern and the kind of antibiotics and to evaluate the using antibiotics based on effectivity. The non-experimental research that was form in a retrospective survey was done through medical record of patient with the lower respiratory infection in the time limit of January-June 2005 in Panti Rapih Hospital. The using of antibiotics was surveyed from medical record then analyzed using quantitative descriptive and presented in percentage. The results obtained showed that the contraindications and adverse reactions of drugs are not found, the incidence of drug interactions by 22 (16\%) of 137 cases and of 29 types of antibiotics are used there are 7 species (24\%) of potential antibiotic drug interactions. Several cases of potential interactions occurs not show clinical manifestations in patients. To avoid unwanted adverse reactions serum creatinine should be monitored especially in the use of aminoglycoside antibiotics group.
\end{abstract}

Keywords: lower respiratory infection, usage, antibiotics evaluation, contraindications, adverse reactions, interactions

\begin{abstract}
ABSTRAK
Infeksi saluran pernapasan bawah non TBC merupakan suatu golongan infeksi yang dapat menyerang bronkus, bronkiolis, dan paru, manifestasi kliniknya dapat bersifat akut dan kronis. Umumnya pada anak-anak penyebabnya adalah virus dan bakteri serta pada orang dewasa penyebabnya adalah bakteri, yang dalam pengobatannya menggunakan antibiotika. Penelitian ini bertujuan mengevaluasi penggunaan antibiotika berdasarkan kontraindikasi, efek samping, dan interaksi obat. Penelitian non eksperimental yang berbentuk survei retrospektif dilakukan melalui rekam medik pasien dengan infeksi saluran pernapasan bawah yang menjalani rawat inap pada kurun waktu Januari-Juni 2005 di RS Panti Rapih Yogyakarta. Penggunaan antibiotika dikaji dari data rekam medik kemudian dianalisis secara deskriftif kuantitatif yang dinyatakan dengan presentase. Hasil penelitian yang diperoleh menunjukan bahwa kontraindikasi dan efek samping obat tidak ditemukan, kejadian interaksi obat sebesar 22 (16\%) dari 137 kasus dan dari 29 jenis antibiotika yang digunakan terdapat 7 jenis (24\%)
\end{abstract}


antibiotika yang potensial terjadi interaksi obat. Beberapa kasus interaksi yang potensial terjadi tidak menunjukan manifestasi klinik pada pasien. Untuk menghindari efek samping yang tidak dikehendaki perlu dilakukan monitoring serum kreatinin terutama pada penggunaan antibiotika golongan aminoglikosida.

Kata Kunci: infeksi saluran pernapasan bawah, penggunaan, evaluasi antibiotika, kontraindikasi, efek samping, interaksi

\section{PENDAHULUAN}

Infeksi saluran pernafasan bawah non TBC merupakan suatu golongan infeksi yang dapat menyerang bronkus, bronkiolus dan paru, manifestasi klinisnya dapat bersifat akut dan kronis. Umumnya pada anak-anak penyebabnya adalah virus dan bakteri, pada orang dewasa penyebabnya adalah bakteri [1]. Saluran pernafasan bawah sangat mudah terkena infeksi oleh bermacammacam mikroorganisme, karena ia adalah salah satu sistem organ yang berhubungan lansung dengan lingkungan [2].

Infeksi saluran pernapasan merupakan penyakit yang banyak diderita masyarakat. Survey kesehatan rumah tangga (2001) menunjukan bahwa $36 \%$ kematian bayi dan $13 \%$ kematian anak balita disebabkan oleh ISPA, juga disebutkan bahwa sebagian besar mortalitas ISPA disebabkan oleh pneumonia. Di daerah Istimewa Yogyakarta infeksi saluran pernafasan bawah merupakan 6,32 \% dari seluruh penyakit, dan merupakan $9,04 \%$ penyakit penyebab kematian. Insidensi tahunan infeksi saluran pernafasan bawah relatif masih sangat tinggi dinegara sedang berkembang seperti Indonesia.

Rachmatullah [3] menyebutkan bahwa infeksi saluran pernafasan bawah banyak ditemukan di Indonesia dengan angka kesakitan dan kematian yang cukup tinggi. Hal ini sangat berbeda dengan insidensi infeksi saluran pernafasan bawah di Amerika serikat relatif sudah rendah, yaitu
4 juta kasus pneumonia pertahun, hanya satu juta diantaranya perlu perawatan rumah sakit [4].

Dari penelusuran awal yang dilakukan terhadap pasien rawat inap dengan diagnosis infeksi saluran pernapasan bawah di Rumah Sakit Panti Rapih Yogyakarta selama periode Januari-Juni 2005, ditemukan 214 kasus dengan berbagai jenis antibiotika yang digunakan.

Banyaknya jenis antibiotika yang beredar saat ini dan adanya kuman yang resisten terhadap beberapa antibiotika, dan di satu sisi pengembangan antibiotika untuk terapi infeksi saluran pernafasan telah banyak menurunkan morbiditas dan mortalitas menyebabkan pemilihan antibiotika yang efektif, efisien, aman dan sedikit efek samping pada pasien infeksi saluran pernafasan semakin kompleks yang memerlukan berbagai pertimbangan baik dari segi kualitas maupun harga yang terjangkau, walaupun dilakukan secara empirik. Selain itu penentuan diagnosis yang tepat sangat diperlukan agar penggunaan obatnya bisa rasional yaitu: tepat indikasi, tepat penderita, tepat obat, tepat dosis, dan waspada terhadap efek samping obat.

Pengaruh interaksi beberapa macam obat yang kita konsumsi secara bersamaan, atau yang lebih dikenal dengan istilah interaksi obat, merupakan salah satu kesalahan pengobatan yang paling banyak dilakukan saat ini. Namun, biasanya kesalahan 
pengobatan karena interaksi obat ini jarang terungkap, karena kekurang-pengetahuan kita, baik dokter, apoteker, apalagi pasien tentang hal ini.

Jika terjadi kegagalan pengobatan, umumnya sangat jarang dikaitkan dengan interaksi obat. Padahal kemungkinan terjadinya interaksi obat ini cukup besar, terutama pada pasien yang mengonsumsi lebih dari 5 macam obat pada saat yang bersamaan. Pada saat ini lebih dari 25 jenis obat baru dilempar ke pasar setiap tahunnya. Dan, tampaknya hampir mustahil jika seorang dokter atau apoteker harus menghafalkan dan menguasai masalah interaksi obat dari sekian ribu macam obat yang beredar sekarang ini. Sebab itu setiap pusat pengobatan modern, apakah itu rumah sakit, puskesmas atau praktek dokter pribadi, dan juga apotek, sebaiknya atau bahkan seharusnya memiliki akses paling tidak ke salah satu pusat data interaksi obat. Agar berbagai macam obat yang diberikan kepada pasien dapat diperhitungkan terlebih dahulu dengan seksama kemungkinan interaksinya.

Ketika dua atau lebih obat dikonsumsi secara bersamaan, akan ada kemungkinan terjadi interaksi. Interaksi yang terjadi ini bisa menambah atau mengurangi efektivitas maupun efek samping obat. Bahkan bisa saja interaksi menyebabkan adanya efek samping baru, yang seharusnya tidak muncul jikalau obat dikonsumsi secara tidak bersamaan. Secara teori, peluang terjadinya interaksi obat sebanding dengan jumlah obat yang dikonsumsi. Karena itu, seseorang yang meng-konsumsi beberapa obat dalam waktu bersamaan, kemungkinan memiliki risiko terjadinya interaksi cukup besar. Adanya interaksi obat juga bisa menyebabkan peningkatan biaya karena adanya kemungkinan efek samping yang harus ditangani. Selain itu interaksi obat juga bisa saja menyebabkan munculnya penyakit yang seharusnya bisa dicegah.

Setiap obat mempunyai kemungkinan untuk menyebabkan efek samping, oleh karena seperti halnya efek farmakologik, efek samping obat juga merupakan hasil interaksi yang kompleks antara molekul obat dengan tempat kerja spesifik dalam sistem biologik tubuh. Kalau suatu efek farmakologik terjadi secara ekstrim, inipun akan menimbulkan pengaruh buruk terhadap sistem biologik tubuh.

Masalah efek samping obat dalam klinik tidak dapat dikesampingkan begitu saja oleh karena kemungkinan dampak negatif yang terjadi, misalnya Kegagalan pengobatan, Timbulnya keluhan penderitaan atau penyakit baru karena obat (drug-induced disease atau iatrogenic disease), yang semula tidak diderita oleh pasien, Pembiayaan yang harus ditanggung sehubungan dengan kegagalan terapi, memberatnya penyakit atau timbulnya penyakit yang baru tadi (dampak ekonomik), efek psikologik terhadap penderita yang akan mempengaruhi keberhasilan terapi lebih lanjut misalnya menurunnya kepatuhan berobat. Sayangnya tidak semua efek samping dapat dideteksi secara mudah dalam tahap awal, kecuali kalau yang terjadi adalah bentuk-bentuk yang berat, spesifik dan jelas sekali secara klinis.

Kontraindikasi berkaitan dengan efek samping yang merugikan, walaupun informasi tentang kontraindikasi dari obat mudah didapatkan, tetapi tidak secara langsung kasus kontraindikasi dapat dipastikan tidak terjadi. Akan diketahui apakah efek samping yang muncul dari penggunaan antibiotik terkait dengan pelanggaran dari kontraindikasi. 
Berdasarkan hal yang disebut di atas, maka perlu dilakukan suatu penelitian untuk melakukan evaluasi kejadian dan kemungkinan interaksi, efek samping, dan kontraindikasi pada penggunaan antibiotik dengan infeksi pernapasan bawah di Rumah Sakit Panti Rapih Yogyakarta periode Januari-Juni 2005.

\section{METODE}

Penelitian ini merupakan penelitian non eksperimen dilakukan dengan rancangan deskriptif evaluatif melalui penelusuran data secara retrospektif terhadap rekam medik penderita infeksi saluran pernapasan bawah yang dirawat di Rumah Sakit Panti Rapih Yogyakarta selama kurun waktu Januari hingga Juni 2005. Diambil seluruh kasus yang memenuhi kriteria inklusi. Ditempuh tahap-tahap penelitian yang merupakan urutan kegiatan.

Bahan penelitian berupa catatan rekam medik pasien rawat inap dengan diagnosis infeksi saluran pernafasan bawah yang dirawat di RS Panti Rapih Yogyakarta selama kurun waktu Januari hingga Juni 2005 yang mendapat terapi anti-biotika, hasil pemeriksaan radiologi, hasil pemeriksaan laboratorium (hasil kultur dan sensitivitas tes, hasil sputum, hasil pemeriksaan darah lengkap).

Alat dalam penelitian ini adalah berupa formulir penelitian terstruktur untuk mencatat data rekam medik penderita infeksi saluran pernapasan bawah. Data yang dikumpulkan dicatat dalam form penelitian meliputi identitas pasien, riwayat penyakit pasien, diagnosis, tanda-tanda vital, pemakaian antibiotika, pemakaian obat lain, pemeriksaan laboratorium (sputum, kultur, sensitivitas dan darah lengkap), pemeriksaan radiologi. Alat penelitian lain berupa SPM RS Panti Rapih Yogyakarta tahun 1998, pedoman penggunaan antibiotik untuk infeksi saluran pernafasan bawah oleh WHO tahun 2003, dan referensi standar terapi yang berkaitan dengan penelitian ini, yaitu untuk infeksi saluran pernapasan bawah.

Penelitian dilaksanakan dalam beberapa tahap. Tahap pertama adalah proses penelusuran dan pengumpulan data. Tahap kedua adalah proses pengolahan data. Tahap ketiga adalah analisis dan evaluasi data, dan tahap keempat adalah pengambilan kesimpulan dan saran.

\section{PEMBAHASAN}

\section{Evaluasi Kontraindikasi}

Penelitian ini bertujuan untuk mengetahui efek samping dan kontraindikasi pemakaian antibiotika, namun karena catatan khusus mengenai efek samping obat tidak tersedia serta lebarnya variasi efek samping obat antara satu pasien dengan yang lainnya, maka penelitian ini hanya bisa mendeteksi kontraindikasi dan kemungkinan telah terjadinya efek samping berupa nefrotoksisitas.

Pada penelitian ini dari total jumlah 132 pasien, walaupun kasus terbesar pada pasien dengan umur anak-anak 0-14 tahun (52\%), tidak ditemukan kasus kontraindikasi pada anak-anak khususnya penggunaan antibiotika fluorokuinolon (perfloksasin dan fleroksasin) yang dikontraindikasikan atau tidak dianjurkan penggunaannya pada anak-anak.

Fauzar (2003) mengatakan bahwa antibiotika golongan fluorokuinolon dikontraindikasikan penggunaannya pada anak-anak berumur kurang dari 16 tahun, karena dapat menyebabkan arthropathy meskipun hal ini masih belum cukup bukti yang meyakinkan, karena keterbatasan uji 
klinik namun pada binatang percobaan kelainan tersebut terjadi.

Doherty (2000) pada penelitian penggunaan siprofloksasin pada pasien anak berumur kurang dari 6 tahun setelah diamati selama 6 bulan didapatkan hasil yang tidak signifikan pada timbulnya efek samping pada sendi atau gangguan pertumbuhan anak. Namun memperhatikan pada binatang percobaan, kelainan tersebut terjadi maka penggunaan kuinolon disarankan hanya digunakan pada kasus infeksi berat dimana antibiotika lain tidak efektif.

Pada penelitian ini dari jumlah total 137 kasus dengan infeksi saluran pernapasan bawah tidak ditemukan penggunaan antibiotika yang dikontraindikasikan pada anak-anak dan tidak ditemukan penggunaan antibiotika yang dikontraindikasikan pada wanita hamil. Pada penelitian ini terdapat pasien dengan usia lanjut > 65 tahun (21\%) tidak ditemukan penggunaan antibiotika yang dikontraindikasikan kecuali pasien hipersensitif. Hal ini memperlihatkan bahwa klinisi cukup peduli dalam mempertimbangkan adanya kontraindikasi penggunaan antibiotika pada pasien anakanak dan wanita hamil.

Evaluasi mengenai kontra-indikasi ini, dapat dijadikan sebagai gambaran keamanan penggunaan antibiotika di Rumah Sakit Panti Rapih Yogyakarta, namun terbatas hanya pada data yang ada di dalam rekam medis pasien.

\section{Efek Samping Obat}

Selain kontraindikasi pe-makaian, aspek lain juga berkaitan dengan keamanan penggunaan antibiotika adalah kejadian efek samping obat yang dapat mempengaruhi atau memperburuk kondisi pasien. Beberapa efek samping yang dapat muncul dengan antibiotika antara lain diare, mual, muntah, gangguan ginjal, hati dan lain-lain. Namun karena alasan yang dijelaskan diatas, maka dalam penelitian ini hanya dapat melihat kemungkinan efek samping obat yang telah terjadi, yang dilihat berdasarkan pemeriksaan laboratorium (dalam hal ini serum kreatinin) karena efek samping yang ingin dilihat adalah nefrotoksisitas yang disebabkan oleh antibiotika golongan aminoglikosida.

Barza dkk (1996) menjelaskan peningkatan nilai kreatinin serum pasien sebesar $50 \%$ diatas base line (sebelum terapi dengan antibiotika yang bersangkutan), dengan memperhatikan obat lain yang digunakan pasien yang juga bersifat nefrotoksik. Dari 132 kasus dengan infeksi saluran pernapasan bawah $29 \%$ yang diukur serum kreatininnya tidak terdapat kasus yang menunjukan kemungkinan telah terjadinya efek toksik pada renal akibat penggunaan aminoglikosida.

\section{Evaluasi Interaksi Obat}

Dalam penelitian ini, adanya interaksi obat yang potensial terjadi, dapat digunakan sebagai salah satu parameter untuk evaluasi keamanan penggunaan antibiotika pada pasien dengan infeksi saluran pernapasan bawah. Kejadian interaksi obat, dapat merupakan interaksi yang aktual terjadi, maupun interaksi yang potensial terjadi.

Interaksi obat yang potensial terjadi, berarti interaksi tersebut secara teoritis dapat terjadi, tetapi secara aktual belum tentu terjadi. Penemuan mengenai interaksi obat potensial yang terjadi adalah sangat penting. Karena dapat berguna sebagai data sehingga para klinisi menjadi waspada apabila mem-berikan terapi obat-obat yang potensial menimbulkan interaksi. 
Evaluasi penggunaan anti-biotika berdasarkan interaksi obat yang potensial terjadi diambil dari data terapi pasien yang tercantum dalam rekam medik, dan tidak dilaporkan adanya interaksi obat yang terjadi secara klinis. Interaksi antibiotika dengan antibiotika atau obat lain secara lengkap dapat dilihat pada tabel 1 .
Dari tabel 1 terlihat ada 7 dari 29 jenis antibiotika yang digunakan, dimana pada penelitian ini terdapat penggunaan antibiotika berinteraksi secara teoritis dengan antibiotika lain atau dengan obat lain yang ditemukan pada 22 kasus (16\%), tetapi tidak diketahui apakah interaksi tersebut secara klinis terjadi karena keterbatasan data penelitian.

Tabel 1. Interaksi antibiotika dengan antibiotika atau dengan obat lain

\begin{tabular}{|c|c|c|}
\hline \multicolumn{3}{|r|}{ Jenis Interaksi Obat } \\
\hline \multirow{9}{*}{$\begin{array}{l}\text { - } \text { Siprofloksasin } \\
\text { - } \text { Ofkloksasin } \\
\text { - } \text { Gatifloksasin } \\
\text { - } \text { Levofloksasin }\end{array}$} & Antasida & Al \& $\quad$ Mg akan membentuk \\
\hline & $\left(\mathrm{Al}(\mathrm{OH})_{3}+\right.$ & kompleks \\
\hline & $\left.\mathrm{Mg}(\mathrm{OH})_{2}\right)$ & fluoroquinolones sehingga sulit \\
\hline & & Absorpsi fluoro \\
\hline & & $\begin{array}{l}50-90 \%, \text { sehingga aktivitas } \\
\text { antibakteri juga akan menurun } 50- \\
90 \%\end{array}$ \\
\hline & $\begin{array}{l}\text { Preparat yang } \\
\text { mengandung } \mathrm{Zn} \\
\text { (multivitamin) }\end{array}$ & $\begin{array}{l}\text { Zink akan membentuk kompleks } \\
\text { (chelate) dengan fluorokuinolones } \\
\text { sehingga sulit diabsorpsi. }\end{array}$ \\
\hline & & $\begin{array}{l}\text { Absorpsi fluoroquinolones menurun } \\
50-90 \%\end{array}$ \\
\hline & $\begin{array}{l}\text { Sukralfat } \\
\left(\mathrm{Al}(\mathrm{OH})_{3}\right)\end{array}$ & $\begin{array}{l}\text { Al akan membentuk kom-pleks } \\
\text { (chelate) dengan fluoroquinolones } \\
\text { sehingga sulit diabsorpsi. }\end{array}$ \\
\hline & & $\begin{array}{l}\text { Absorpsi fluoroquinolones menurun } \\
50-90 \% \text {. }\end{array}$ \\
\hline
\end{tabular}

Sefotaksim Gentamisin

Berefek sinergistik, meningkatkan efek nefrotoksik gentamisin

Berikan kuinolon minimal 4 jam sebelum atau 6 jam sesudah pemberian sukralfat, bila terpaksa harus diberikan kurang dari itu monitor efek terapetik kuinolon yang mungkin berkurang

Berikan kuinolon minimal 2 jam sebelum atau 4 jam sesudah pemberian antasida atau garam Fe dan $\mathrm{Zn}$, bila terpaksa harus diberikan kurang dari itu monitor efek terapetik kuinolon yang mungkin berkurang

Monitor efek samping dan toksisitas dari gentamisin, jika perlu mempertimbangkan penyesuaian dosis sesuai dengan kondisi klinis pasien.

Seftriakson Furosemid Furosemid meningkatkan efek Furosemid diberikan 3-4 jam nefrotoksik sefalosporin dengan sebelum sefalosporin losporin

Pada penelitian ini walaupun dari pengamatan efektivitas tidak seluruhnya terpengaruh, tetapi dengan menghindari terjadinya interaksi obat, diharapkan bisa meningkatkan hasil pengobatan yang dicapai. Secara rinci interaksi antara antibiotika dengan antibiotika atau obat lain adalah sebagai berikut: a. Interaksi antara fluoro-kuinolon (ofloksasin, siprofloksasin, dan levofloksasin) dengan antasida (Al dan $\mathrm{Mg}$ hidroksida) terdapat 9 kasus. Antasida dapat menurunkan absorpsi fluorokuinolon di usus karena terbentuk chelate, sehingga menurunkan aktivitas antibakterinya. Untuk menghindari hal 
tersebut maka antasida diberikan minimal 2 jam sesudah penggunaan antibiotika, walaupun absorpsi masih berkurang 20-40\%. Hasil pengobatan pada kasus ini adalah sembuh 4 kasus, membaik 2 kasus, dan belum sembuh/APS 3 kasus. Pemberian antibiotika dengan an-tasida di Rumah Sakit Panti Rapih pemberiannya sudah dipisahkan.

b. Interaksi antara fluorokuinolon (levofloksasin) dengan sukralfat terdapat pada 1 kasus. Sukralfat dapat menurunkan absorpsi fluoro-kuinolon di usus karena terbentuk chelate, sehingga menurunkan aktivitas antibakterinya. Untuk menghin-dari hal tersebut maka sukralfat diberikan minimal 2 jam sesudah penggunaan antibiotika. Pemberian anti biotika dengan sukralfat di Rumah Sakit panti rapih pemberiannya sudah dipisahkan.

c. Interaksi antara fluoro-kuinolon (ofloksasin, levo-floksasin, dan gatifloksasin) dengan preparat yang mengandung zink (multivitamin) terdapat pada 7 kasus. Zink akan membentuk chelate dengan fluorokuinolon dan akan menurunkan aktivitas anti-bakterinya. Untuk menghindari hal tersebut maka zink (multivitamin) diberikan minimal 2 jam sesudah penggunaan antibiotika. Hasil pengobatan pada kasus ini adalah sembuh 4 kasus, membaik 3 kasus, (tetap) tidak sembuh 1 kasus dan meninggal 1 kasus.

d. Interaksi antara seftriakson dan furosemid terdapat pada 2 kasus. Furosemid dapat meningkatkan 25\% half life dari sefalosporin (seftriakson) dan menurunkan klirens dari sefalosporin, sehingga meningkatkan efek nefro-toksiknya. Interaksi seftriakson dengan furosemid efek nefrotoksisitasnya tidak signifikan. Namun pada kasus ini tetap perlu dimonitor fungsi ginjal sebelum dan sesudah terapi, untuk melihat apakah ada penurunan pada fungsi ginjalnya. Hasil pengobatan pada kasus ini adalah membaik.

Interaksi antara sefotaksim dan gentamisin terdapat 2 kasus. Berefek sinergistik namun pada kasus ini tetap perlu dimonitor fungsi ginjal sebelum dan sesudah terapi, untuk melihat apakah ada penurunan pada fungsi ginjalnya. Hasil pengobatan pada kasus ini adalah membaik dan tidak sembuh (tetap).

\section{KESIMPULAN}

Tidak ditemukan kasus kontraindikasi pada wanita hamil dan penggunaan golongan fluorokuinolon pada anak-anak yang menggambarkan ketidakamanan sehingga perlu pemantauan terapi. Tidak ditemukan kasus yang menunjukan kemungkinan telah terjadinya efek toksik pada renal akibat penggunaan aminoglikosida. Ditemukan $16 \%$ kasus potensial interaksi obat pada penggunaan fluorokuinolon dengan antasida, sukralfat dan preparat yang mengandung zink (multivitamin) serta penggunaan sefalosporin generasi ketiga dengan gentamisin dan furosemid yang menggambarkan ketidakamanan terapi, sehingga perlu diwaspadai dan diminimalkan kejadiannya.

\section{UCAPAN TERIMA KASIH}

Kepada Pimpinan Rumah Sakit Panti Rapih yang telah bersedia memberikan kesempatan untuk melakukan penelitian.

\section{DAFTAR PUSTAKA}

1. Rasmin, M. 1997, Infeksi Saluran Nafas Bawah, M.K.I, 47, (6), 271-272.

2. Schulman, S.T.; Phair, J.; \& Sommers, H. 1994, The Biologic \& Clinical Basic of Infectious Diseases, Fourth Edition, wahab, S., Editor Edisi Bahasa Indonesia, Dasar Biologis 
Evaluasi Penggunaan Antibiotika Berdasarkan Kontraindikasi, Efeksamping, dan Interaksi Obat Pada Pasien Rawat Inap Dengan Infeksi Saluran Pernapasan Bawah di Rumah Sakit Panti Rapih Yogyakarta Periode Januari-Juni 2005

\& Klinis Penyakit Infeksi, Fakultas Kedokteran UGM, Gadjah Mada University Press, Yogyakarta, 521-535, 606-607

3. Rachmatullah. 1996, Infeksi Saluran Nafas Bawah Akut Pada Orang Dewasa, M.K.I, 44 (8), 486-494.
4. Halm, E.A.; \& Teirstein, A.S. 2002, Management of Community-Acquiered Pneumonia, NEJM, 347: 2039-2045. 